UDC 616-001.28 + 577.125: 577.346

doi: https://doi.org/10.15407/ubj91.03.099

\title{
LIPID PROFILE PARAMETERS AND OXIDATIVE PROCESSES INTENSITY IN THE PERSONS WHO HAVE BEEN AFFECTED BY LOW DOSES OF RADIATION
}

\author{
V. L. SOKOLENKO, S. V. SOKOLENKO \\ Bohdan Khmelnytsky National University of Cherkasy, Ukraine; \\ e-mail:sokolenko@ukr.net
}

Received: 10 October 2018; Accepted: 14 March 2019

The aim of the work was to analyze the relationship between the main parameters of lipid metabolism and the intensity of oxidative processes among the inhabitants of the territories contaminated by radionuclides as a result of the Chornobyl accident. We examined 50 persons from the control group and 50 persons from the territories of strengthened radioecological control (density of soil contamination by isotopes ${ }^{137} \mathrm{Cs}$ 3.7 $\cdot 10^{4}-18.5 \cdot 10^{4} \mathrm{~Bq} / \mathrm{m}^{2}, 50$ persons). All examined were the students aged 18 to 24 , who had no acute illnesses during the study. We determined the parameters of lipid metabolism, oxidative processes and antioxidant system. A positive correlation of all analyzed lipid metabolism parameters (except for HDL-C) with MDA, ceruloplasmin and the index of oxidative stress was discovered. The highest values of correlation coefficients with oxidative stress indices were observed for low-density lipoprotein cholesterol. Under the conditions of additional emotional stress, the correlation coefficients between the main lipid metabolism and the intensity of oxidative processes increased. Persons who lived for a long time in areas contaminated with radionuclides form the risk group for the development and progression of inflammatory processes. The risk increases under the influence of additional factors of a stressful nature.

Ke y words: ChNPP, low doses of radiation, lipid profile, oxidative processes.

$\mathrm{T}$ he population of the territories contaminated by radionuclides as a result of the Chornobyl accident continues to experience prolonged exposure to low doses of ionizing radiation. It is supposed that daily consumption of food grown in the zone of enhanced radioecological control remains the main source of internal radiation exposure, mostly with cesium-137 $\left({ }^{137} \mathrm{Cs}\right)$. Although the effects of the long-term internal accumulation of radionuclides have been studied superficially, there is the evidence of lipid metabolism violations in this case (in particular cholesterol metabolism) [1].

Among the sons of the liquidators of Chornobyl accident consequences, there is an increase of neuroendocrine obesity, accompanied by characteristic changes in the level of lipoproteins [2]. Similar tendencies among people who have been living for a long time in the areas contaminated with radio- nuclides are considered as significant factors in the development of atherosclerosis and other cardiovascular disorders [3].

Typical signs of metabolic syndrome, described in the scientific literature (dyslipidemia, characterized by increased level of triglycerides and LDL-C, lowered level of HDL-C) are closely related to elevated oxidative stress and endothelial dysfunction [4-8].

Oxidation processes in the body are activated in conditions of radiation exposure and have qualitative differences from spontaneous (in physiological conditions) [9]. Radiological products with high oxidation or reducing activity lead to stimulation of lipid peroxidation reactions, which in turn, have a damaging effect on the background of enzyme and non-enzyme antioxidant systems exhaustion [10].

(C) 2019 Sokolenko V. L., Sokolenko S. V. This is an open-access article distributed under the terms of the Creative Commons Attribution License, which permits unrestricted use, distribution, and reproduction in any medium, provided the original author and source are credited. 
The study of lipid metabolism and redox homeostasis in residents of radiation-polluted areas relates mainly to the patients with severe pathologies and therefore require further analysis.

The purpose of the work is to find out the specifics of the relationship between the main parameters of lipid metabolism and the intensity of oxidative processes among the inhabitants of the territories contaminated by radionuclides as a result of the Chornobyl accident.

\section{Materials and Methods}

There were examined 100 persons, including a group of people from non-contaminated areas (control group, 50 persons) and inhabitants of territories of the strengthened radio-ecological control (IV radiation zone, a density of soil pollution with isotopes ${ }^{137} \mathrm{Cs} 3.7 \cdot 10^{4}-18.5 \cdot 10^{4} \mathrm{~Bq} / \mathrm{m}^{2}$, 50 persons). All examined are the students of Cherkassy National University, aged 18-24, at the time of research not having any acute diseases. There was no statistically significant difference between volunteers of different sex (females were examined in the follicular stage of the menstrual cycle), so they are considered as a single group in the future.

Winter examination session played the role of additional stress factor, which predetermined the development of psycho-emotional load. $15 \mathrm{ml}$ of venous blood was taken in the morning, before eating. The first analysis of the blood parameters was made in the inter-session period, the second after the first exam. Medical examinations and blood sampling were taken by qualified medical staff on the basis of "Edem" sanatorium at Cherkasy National University and the biochemical laboratory of the City Hospital $\mathrm{N} 1$ in Cherkasy city.

The research was conducted in compliance with the ethical principles of the European Convention and the Helsinki Declaration, all examined agreed for test taking and results publishing.

Total cholesterol (TC) level in serum was determined on the basis of the Lieberman-Burhard reaction (Ilka method). High-density lipoprotein cholesterol (HDL-C) level was determined on the basis of the Lieberman-Burhard reaction after lowdensity lipoprotein cholesterol (LDL-C) sedimentation by interaction with $\mathrm{MgCl}_{2}$ and phosphotungstic acid hydrate. The content of triglycerides (TG) in serum was determined by a standardized method of reaction with acetylacetone after extraction with a mixture of heptane and isopropyl alcohol [11].
The content of low-density lipoprotein cholesterol (LDL-C) was determined by Friedewald formula: LDL-C = TC - (HDL-C + TG/2.2) [12].

We have studied the components of oxidative processes and antioxidant system by procedure [13]. The content of malondialdehyde (MDA), ceruloplasmin (CP), transferrin (TR) and sulfhydryl groups (SH) were determined.

The calculation of the oxidative stress index (OSI) was made by the formula:

OSI = MDAe/MDAc: [(CPe/CPc + TRe/TRc + + SHe/SHc): 3],

where OSI is an index of oxidative stress; MDAe the content of MDA in the experimental group; MDAc - MDA in control group (average); $\mathrm{CPe}-$ content of CP in experimental group; CPc - CP in control group (average); TRe-content of TR in the experimental group; TRc - TR in the control group (average); $\mathrm{SHe}$ - the content of $\mathrm{SH}$ in the experimental group; SHc-SH in the control group (average); $3-$ number of components [13].

Kinetic and statistical calculations were performed by using MS Office computer software. The data are expressed as mean \pm standard error $(\mathrm{M} \pm \mathrm{SE})$.

Normality of distribution of oxidation index, antioxidant system and lipid metabolism was confirmed using Shapiro-Wilk Test. Samples comparison was carried out by Student's $t$-test. Distinction significance is indicated by three thresholds:

$\mathrm{t}_{\mathrm{st}}\{2.02(P<0.05)-2.70(P<0.01)-3.55$ $(P<0.001)\}$

Correlation analysis was performed using the Pearson correlation coefficient.

Correlation coefficient significance is determined by the formula:

$\mathrm{t}_{\mathrm{r}}=\mathrm{r} / \mathrm{m}_{\mathrm{r}} \geq \mathrm{t}_{\mathrm{st}}\{\mathrm{v}=\mathrm{N}-2\}$, where $\mathrm{t}_{\mathrm{r}}$ is correlation coefficient significance criterion; $r$ - sample correlation coefficient; $\mathrm{m}_{\mathrm{r}}$ - sample correlation coefficient error; $\mathrm{N}$ - number of correlated pairs of values; $\mathrm{t}_{\mathrm{st}}$ is the standard value of Student's criterion. Sample correlation coefficient error mr was determined by the formula:

$$
\mathrm{m}_{\mathrm{r}}=\sqrt{ }\left(\left(1-r^{2}\right) /(\mathrm{N}-2)\right) \text {. }
$$

If the calculated value $t_{r}$ is more than tabular by Student, the correlation coefficient is considered as significant. Significance was indicated for $v=48(\mathrm{~N}-2)$ by three thresholds:

$$
\mathrm{t}_{\mathrm{st}}\{2.02(P<0.05)-2.70(P<0.01)-3.55
$$
$(P<0.001)\}$. 


\section{Results and Discussion}

We established that in the group of examined from the areas of strengthened radioecological control the level of total cholesterol, triglycerides, cholesterol of high and low-density lipoproteins is significantly higher than in the control group. The effect was accompanied by a tendency to increase in the level of malonic dialdehyde (the difference with the control group did not have any statistical significance) and a significant decrease in the content of sulfhydryl compounds (Table).

Under the conditions of additional emotional stress caused by the examination session, in the experimental group, there was a tendency towards an increase in the level of total cholesterol and triglycerides (with cholesterol on the upper limit of the homeostatic norm), a significant increase in the level of cholesterol of low density lipoproteins (on the upper limit of the norm) and decrease in cholesterol of high-density lipoproteins (Table).

The additional emotional load as a result of the examination session led to increasing the level of malondialdehyde in the control group and a sig- nificant increase of the parameter for students who came to study from the territories of enhanced radioecological control. At the same time, both groups showed a significant increase of sulfhydryl compounds in serum. Examined from the experimental group showed significantly lower coefficient than in the control under the same conditions. MDA is a marker of lipid peroxidation that is an auto-catalytic free radical process [14]. The sulfhydryl groups SH are important antioxidant components [15]. Thus, the compensation efficiency of the oxidative processes intensification in the group of people from radiation contaminated territories was lower than in the control group (Table).

True changes in the level of ceruloplasmin and transferrin have been detected neither in the control nor in the experimental groups.

Ceruloplasmin and transferrin are considered to be important antioxidants that show acting interconsistency $[16,17]$. Ceruloplasmin controls the membrane oxidation of lipids, preventing their peroxidation [18]. Thus, the lack of changes in the level of antioxidants on the background of MDA growth in individuals, who have undergone prolonged expo-

Cortisol, lipid profile and oxidative-antioxidant system parameters in the examined group

\begin{tabular}{|c|c|c|c|c|}
\hline \multirow{2}{*}{ Components } & \multicolumn{2}{|c|}{ Control } & \multicolumn{2}{|c|}{$\begin{array}{l}\text { Experimental group: people } \\
\text { undergoing the prolonged } \\
\text { influence of low radiation dose }\end{array}$} \\
\hline & $\begin{array}{l}\text { before } \\
\text { emotional } \\
\text { stress }\end{array}$ & $\begin{array}{c}\text { during emotional } \\
\text { stress }\end{array}$ & $\begin{array}{l}\text { before emotional } \\
\text { stress }\end{array}$ & $\begin{array}{l}\text { during emotional } \\
\text { stress }\end{array}$ \\
\hline Cortisol, nmol/l & $351.12 \pm 10.14$ & $801.25 \pm 12.54^{\# \# \#}$ & $633.48 \pm 22.16^{* * *}$ & 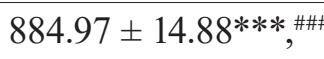 \\
\hline Total cholesterol, mmol/l & $3.06 \pm 0.28$ & $3.29 \pm 0.32$ & $6.02 \pm 0.88^{* *}$ & $6.99 \pm 0.55^{* *}$ \\
\hline Triglycerides, mmol/l & $0.52 \pm 0.08$ & $0.54 \pm 0.08$ & $0.95 \pm 0.09 * * *$ & $1.11 \pm 0.07 * * *$ \\
\hline $\begin{array}{l}\text { High density lipoprotein } \\
\text { cholesterol, mmol/l }\end{array}$ & $1.07 \pm 0.07$ & $0.99 \pm 0.08$ & $1.54 \pm 0.07 * * *$ & $0.93 \pm 0.07^{\# \# \#}$ \\
\hline $\begin{array}{l}\text { Low density lipoprotein } \\
\text { cholesterol, mmol/l }\end{array}$ & $1.82 \pm 0.11$ & $2.04 \pm 0.14$ & $4.05 \pm 0.35^{* * *}$ & 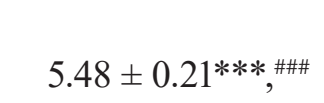 \\
\hline Malondialdehyde, mmol/l & $125.41 \pm 27.51$ & $150.75 \pm 36.41$ & $136.31 \pm 14.15$ & $200.65 \pm 24.14^{\#}$ \\
\hline Ceruloplasmin, g/l & $0.24 \pm 0.02$ & $0.27 \pm 0.03$ & $0.22 \pm 0.03$ & $0.21 \pm 0.02$ \\
\hline Transferrin, cond. un. & $5.33 \pm 1.01$ & $5.50 \pm 1.02$ & $4.39 \pm 0.90$ & $4.25 \pm 1.15$ \\
\hline SH-groups, mmol/l & $2.52 \pm 0.03$ & $2.73 \pm 0.07^{\# \#}$ & $1.70 \pm 0.04 * * *$ & 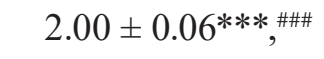 \\
\hline $\begin{array}{l}\text { Oxidative stress } \\
\text { index, un. }\end{array}$ & $1.03 \pm 0.04$ & $1.10 \pm 0.05$ & $1.41 \pm 0.05^{* * *}$ & 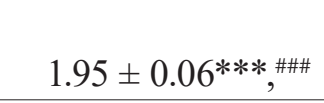 \\
\hline
\end{tabular}

Notes: $* * P<0.01 ; * * * P<0.001$ : a significant difference between the experimental and control groups under similar conditions; ${ }^{\#} P<0.05$; ${ }^{\#} P<0.01$; ${ }^{\# \#} P<0.001$ : a significant change of the parameters in the group under conditions of psycho-emotional load; ( $\mathrm{M} \pm \mathrm{SE}, n=50)$ 
sure to low dose radiation, can indicate the radiationinduced suppression of the antioxidant status of the organism. As a result, the index of oxidative stress in the examined group has become significantly higher compared with the control (Table).

The specifics of the lipid profile and the oxidative-antioxidant system detected in the experimental group were evident on the background of increased cortisol level in serum compared to control. In conditions of additional emotional stress, the level of cortisol increased both in the control group and in the experimental group (Table).

The specifics of cortisol level in persons who came to study from the territories of enhanced radioecological control are described in detail in our previous notifications [19-21]. Cortisol can significantly affect the processes of lipid metabolism: increases lipoprotein lipase activity, increases the level of LDL$\mathrm{C}$, reduces receptor formation to LDL-C, inhibiting their absorption by cells and eliminating cholesterol from the bloodstream, increases the activity of lipase releasing fatty acids from deposited triglycerides. The greatest value of corticoid hormones in the development of lipid metabolism disorders is manifested in conditions of chronic psychological stress, depression, low social-economic status [22-24].

We reported a positive correlation between the level of cortisol with the levels of TC (total cholesterol), LDL-C, MDA and the value of the oxidative stress index in persons who had undergone a chronic exposure to low doses of ionizing radiation [21, 25]. Analysis of the correlation between the lipid profile and the oxidative-antioxidant balance of the examined from the territories of intensified radioecological control showed that significant positive correlations with the level of MDA, ceruloplasmin and the index of oxidative stress are typical for all of the analyzed lipid metabolism parameters except for the HDL-C (Fig. 1-4). And for HDL-C no reliable correlation dependencies were found (Fig. 3). The level of total cholesterol (under conditions of additional psychoemotional loading) (Fig. 1) and the level of LDL-C (both in the absence and presence of additional psycho-emotional load) are correlated with the level of sulfhydryl compounds (Fig. 4).

The highest values of the correlation coefficients with the oxidative-antioxidant system parameters were observed for low-density lipoprotein cholesterol, in particular, with MDA levels $(r=0.59$ in the absence and $r=0.68$ in presence of additional emotional stress) and the index of oxidative stress ( $r=0.65$ in absence and $r=0.75$ in presence of additional emotional stress) (Fig. 4).

An increase in the level of malondialdehyde is one of the main signs of lipid peroxidation activation and an oxidative stress biomarker.

Reactive oxygen forms can change the functions and chemical structure of membrane lipids [26, 27]. Accordingly, oxidative stress is involved in pathological processes, such as atherogenic effects, cardiovascular diseases and obesity. Moreover, obesity, in turn, can lead to systemic oxidative stress. Oxidative processes, in particular, lipid peroxidation, correlate with the levels of total cholesterol, LDL-C and triglycerides [26], which corresponds to the data obtained in the study.

A characteristic feature of the revealed specifics of the relationship between the main parameters of lipid metabolism and the intensity of oxidative processes in the experimental group was the increase in the value of correlation coefficients under conditions of additional emotional stress (Fig. 1-4). It is known that prolonged chronic stress leads to adverse quantitative changes not only in the concentration of cor-

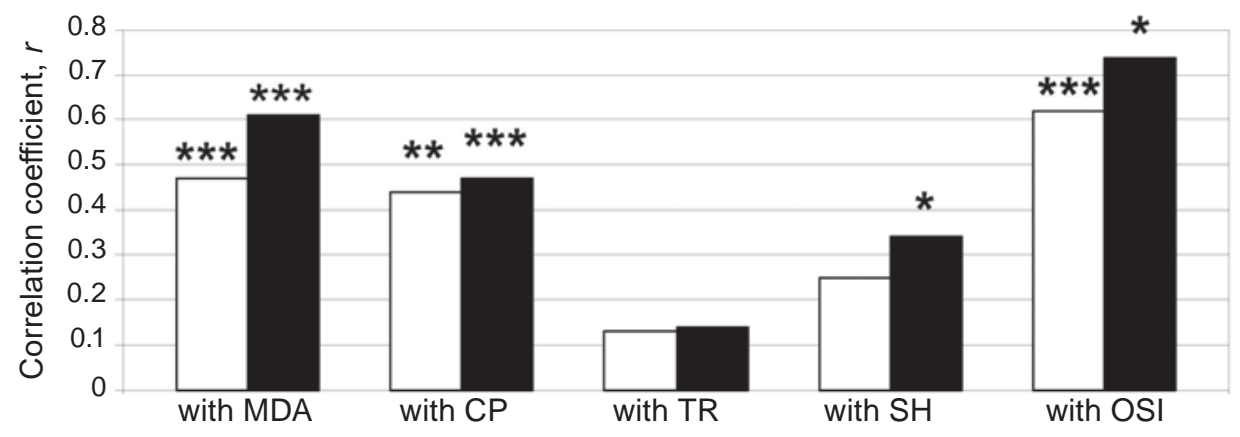

Fig. 1. Correlation coefficient indexes between the level of total cholesterol and the parameters of the oxidative antioxidant system in the absence (white) and presence (black) of additional emotional load in persons from radiation contaminated territories, $n=50 ; * P<0.05 ; * * P<0.01 ; * * * P<0.001$ 


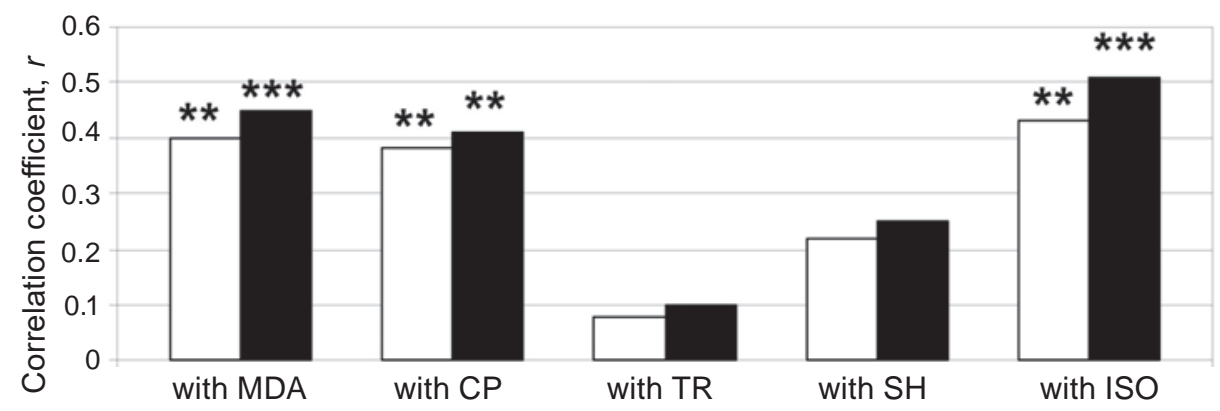

Fig. 2. Correlation coefficient indexes between the level of triglycerides and the parameters of the oxidative antioxidant system in the absence (white) and presence (black) of additional emotional load in persons from radiation contaminated territories, $n=50$; $* * P<0.01 ; * * * P<0.001$

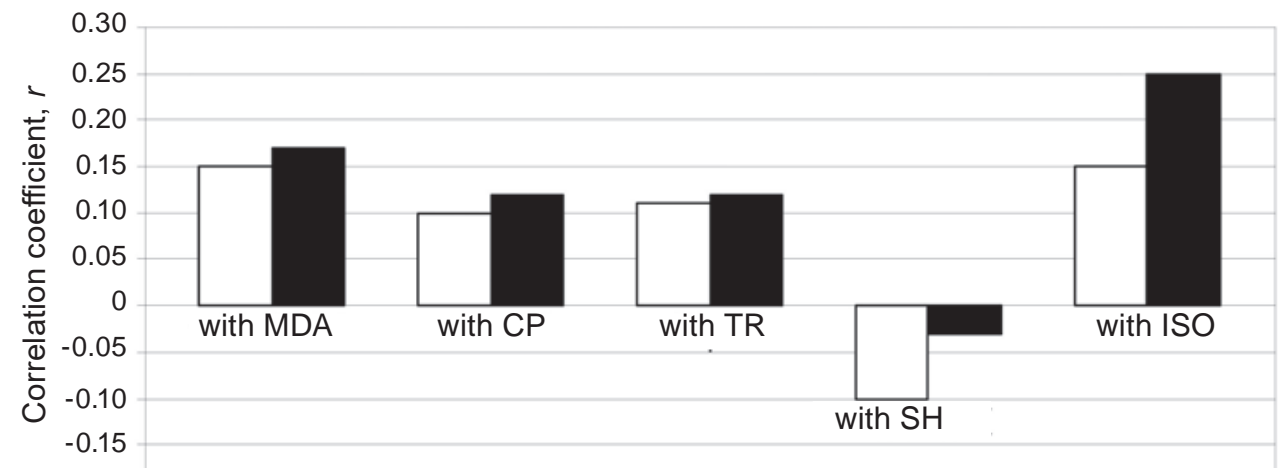

Fig. 3. Correlation coefficient indexes between the level of high-density lipoprotein cholesterol and parameters of the oxidative antioxidant system in the absence (white) and presence (black) of additional emotional load in persons from radiation-contaminated territories, $n=50$

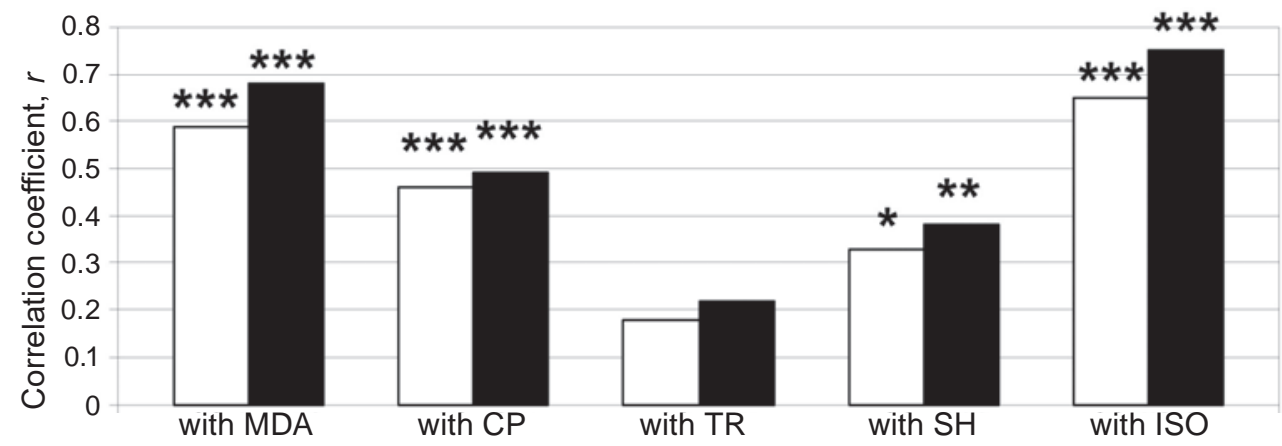

Fig. 4. Correlation coefficient indexes between the level of low-density lipoprotein cholesterol and parameters of oxidative-antioxidant system in the absence (white) and presence (black) of additional emotional load in persons from radiation-contaminated territories, $n=50$; ${ }^{*}<<0.05$; ${ }^{* *} P<0.01 ; * * * P<0.001$

ticosteroids but also in the lipid spectrum of blood serum: dyslipidemia, accumulation of abdominal fat $[28,29]$. In turn, metabolic disorders, in particular, hypercholesterolemia, are considered as the possible factors of the formation of depressive states, especially in women [30]. Generally, in many cases, it is difficult to determine the primary or secondary effects of corticoid hormones and lipid metabolism factors [22-24].

On the one hand, in our studies, the parameters of oxidative processes in the group of examined people did not go beyond the homeostatic norm. Doctors did not find any significant signs of a health disorder. However, all students who came to study from ter- 
ritories contaminated with radionuclides showed inhibition of cellular immunity parameters compared to control [19, 31]. The increase in the level of total cholesterol and cholesterol of low-density lipoproteins was often accompanied by the formation of a syndrome of vegetative-vascular dystonia [21, 32]. Perhaps the absence of noticeable changes in redox homeostasis was due to the fact that radiation-induced oxidative processes are clearly manifested in acute irradiation [9]. In the range of low doses, the consequences are rather ambiguous and, apparently, depend on certain additional factors [33].

On the other hand, it should be taken into account that the increase of malondialdehyde level among the liquidators of the consequences of the Chernobyl accident is considered to be a risk factor for the activation and chronization of inflammatory processes [34]. Acute inflammations are accompanied both by the intensification of oxidative stress and the signs of a metabolic syndrome associated with lipid metabolism disorders [35]. The formation of the active forms of oxygen by phagocytic cells significantly contributes to the development of inflammation [26].

Previously, we have shown that in persons who suffered from chronic effects of low doses of radiation, the level of LDL-C positively correlated with the number of immature professional phagocytes stab neutrophils [21]. According to the literature, hypercholesterolemia can stimulate the development of neutrophils in the bone marrow and spleen, which, in turn, creates the preconditions for the formation of inflammatory reactions [36].

Thus, the revealed specifics of the lipid profile, oxidative processes and their relations among persons aged 18-24 who lived for a long time in areas contaminated with radionuclides were identified as a risk factor of inflammatory processes development and their chronization. The risk increases under the influence of additional factors of a stressful nature. Analyzing the positive effect of normobaric hypoxia on the cellular immunity of this group [37], it is worth to take into consideration the effectiveness of this therapy on redox homeostasis normalization.

The authors express their sincere gratitude to the chief physician of the "Edem" sanatorium at the Cherkasy National University Pinkovska L. O. for the examination of the experimental and control groups of students and assessment of their health status, and to the medical staff of the sanatorium and the biochemical laboratory of the City Hospital N 1 of Cherkasy city for blood sampling.

Conflict of interest. Authors have completed the Unified Conflicts of Interest form at http:// ukrbiochemjournal.org/wp-content/uploads/2018/12/ coi_disclosure.pdf and declare no conflict of interest.

\section{ПОКАЗНИКИ ЛІПІДНОГО ПРОФІЛЮ ТА ІНТЕНСИВНОСТІ ОКИСНИХ ПРОЦЕСІВ В ОСІБ, ЯКІ ЗАЗНАЛИ ПРОЛОНГОВАНОГО ВПЛИВУ МАЛИХ ДОЗ РАДІАЦІЇ}

\section{В. Л. Соколенко, С. В. Соколенко}

\author{
Черкаський національний університет \\ імені Богдана Хмельницького, Україна; \\ e-mail: sokolenko@ukr.net
}

Метою роботи був аналіз взаємозв'язку між основними показниками ліпідного обміну та інтенсивністю окисних процесів у мешканців територій, забруднених радіонуклідами внаслідок аварії на ЧАЕС. Обстежено 50 осіб з контрольної групи та 50 осіб із територій посиленого радіоекологічного контролю (щільність забруднення грунтів ізотопами ${ }^{137} \mathrm{Cs} 3,7 \cdot 10^{4}-18,5 \cdot 10^{4}$ Бк/ $\mathrm{M}^{2}, 50$ осіб). Всі обстежені - студенти віком 18-24 років, котрі на час обстеження не мали гострих захворювань. Визначали показники ліпідного обміну, окисних процесів та антиоксидантної системи. Виявили позитивні кореляційні зв'язки всіх показників ліпідного обміну (крім Хс-ЛПВЩ) 3 рівнем МДА, церулоплазміну та індексом окисного стресу. Найвищі значення коефіцієнтів кореляції з показниками окисного стресу відмічено для холестеролу ліпопротеїнів низької щільності. За умов додаткового емоційного стресу значення коефіцієнтів кореляції між основними показниками ліпідного обміну та інтенсивністю окисних процесів зростали. Особи, які тривалий час проживали на територіях, забруднених радіонуклідами, становлять групу ризику розвитку та хронізації запальних процесів. Ризик зростає за умов впливу додаткових факторів стресової природи.

К лю чов і слов а: ЧАЕС, малі дози радіації, ліпідний профіль, окисні процеси. 


\section{References}

1. Racine R, Grandcolas L, Grison S, Gourmelon P, Guéguen Y, Veyssière G, Souidi M. Molecular modifications of cholesterol metabolism in the liver and the brain after chronic contamination with cesium 137. Food Chem Toxicol. 2009; 47(7): 1642-1647.

2. Korenev MM, Plekhova OI, Kalmykova NV, Kashina VL, Borisko GO. Some features of blood lipid spectrum in descedants of the Chernobyl consequences liquidators. Sovrem Pediatrija. 2009; 3(25): 56-58. (In Ukrainian).

3. Bruno RM, Sicari R, Corciu AI, Bianchini E, Faita F, Di Stefano R, Antonelli A, Ghiadoni L, Picano E. Non-cancer atherosclerotic effects associated with environmental and therapeutic radiation doses: the Chernobyl thyroid cancer children study. Int J Cardiol. 2013; 168(4): 42554257.

4. Barter P, Gotto AM, LaRosa JC, Maroni J, Szarek M, Grundy SM, Kastelein JJ, Bittner V, Fruchart JC. HDL cholesterol, very low levels of LDL cholesterol, and cardiovascular events. $N$ Engl J Med. 2007; 357(13): 1301-1310.

5. Kaur J. A comprehensive review on metabolic syndrome. Cardiol Res Pract. 2014; 2014: 943162.

6. Prasad H, Ryan DA, Celzo MF, Stapleton D. Metabolic syndrome: definition and therapeutic implications. Postgrad Med. 2012; 124(1): 21-30.

7. Roberts CK, Sindhu KK. Oxidative stress and metabolic syndrome. Life Sci. 2009; 84(21-22): 705-712.

8. Furukawa S, Fujita T, Shimabukuro M, Iwaki M, Yamada Y, Nakajima Y, Nakayama O, Makishima M, Matsuda M, Shimomura I. Increased oxidative stress in obesity and its impact on metabolic syndrome. J Clin Invest. 2004; 114(12): 1752-1761.

9. Combs Jr GF, Combs SB. The role of selenium in nutrition. Academic Press, Orlando. FL, 1986. $532 \mathrm{p}$.

10. Dostert P, Benedetti MS, Frigerio E. Effect of L-dopa, oxyferriscorbone and ferrous iron on in vivo lipid peroxidation. $J$ Neural Transm Gen Sect. 1991; 84(1-2): 119-128.

11. Menshikov VV, Delektorskaya LN, Zolotnitskaya RP et al. Laboratory Research Methods at the Clinic: Directory. Ed. V. Menshikov. M.: Medicine, 1987. 368 p.
12. Friedewald WT, Levy RI, Fredrickson DS. Estimation of the concentration of low-density lipoprotein cholesterol in plasma, without use of the preparative ultracentrifuge. Clin Chem. 1972; 18(6): 499-502.

13. Pat. 102192 UA, CIP G01N 33/48. Method of integral evaluate of oxidant-antioxidant balance in blood serum / Korol LV, Myhal LA. Publ. 10.06.2013, Bul. N 11. (In Ukrainian).

14. Knight JA. Review: Free radicals, antioxidants, and the immune system. Ann Clin Lab Sci. 2000; 30(2): 145-158.

15. Birben E, Sahiner UM, Sackesen C, Erzurum S, Kalayci O. Oxidative stress and antioxidant defense. World Allergy Organ J. 2012; 5(1): 9-19.

16. Memişoğullari R, Bakan E. Levels of ceruloplasmin, transferrin, and lipid peroxidation in the serum of patients with Type 2 diabetes mellitus. J Diabetes Complications. 2004; 18(4): 193-197.

17. Somogyi A, Rosta K, Pusztai P, Tulassay Z, Nagy G. Antioxidant measurements. Physiol Meas. 2007; 28(4): R41-R55.

18. Taysi S, Polat F, Gul M, Sari RA, Bakan E. Lipid peroxidation, some extracellular antioxidants, and antioxidant enzymes in serum of patients with rheumatoid arthritis. Rheumatol Int. 2002; 21(5): 200-204.

19. Sokolenko VL. Impact of emotional stress on the immune system indices among residents of radiation contaminated areas. Fiziol Zh. 2016; 62(4): 53-59. (In Ukrainian).

20. Sokolenko VL, Sokolenko SV. Interactions between immune system parameters and thyroid status in people from radioactive contaminated areas by the conditions of emotional stress. Fiziol Zh. 2017; 63(3): 32-39. (In Ukrainian).

21. Sokolenko VL, Sokolenko SV. The interaction between lipid exchange and thyroid status in the conditions of prolonged influence of small doses of radiation. Regul Mech Biosyst. 2017; 8(2): 231238. (In Ukrainian).

22. Brotman DJ, Golden SH, Wittstein IS. The cardiovascular toll of stress. Lancet. 2007; 370(9592): 1089-1100.

23. Engelking LR. Textbook of Veterinary Physiological Chemistry, Updated 2/e. Academic Press. 2010. 573 p.

24. Toth PP, Grabner M, Punekar RS, Quimbo RA, Cziraky MJ, Jacobson TA. Cardiovascular risk in patients achieving low-density lipoprotein 
cholesterol and particle targets. Atherosclerosis. 2014; 235(2): 585-591.

25. Sokolenko VL, Sokolenko SV. Specifics of oxidant and antioxidant systems in residents of the territories contaminated with radionuclides. Bull Probl Biol Med. 2016; 1(133): 176-180. (In Ukrainian).

26. Fernández-Sánchez A, Madrigal-Santillán E, Bautista M, Esquivel-Soto J, MoralesGonzález A, Esquivel-Chirino C, DuranteMontiel I, Sánchez-Rivera G, Valadez-Vega C, Morales-González JA. Inflammation, oxidative stress, and obesity. Int J Mol Sci. 2011; 12(5): 3117-3132.

27. Leonard B, Maes M. Mechanistic explanations how cell-mediated immune activation, inflammation and oxidative and nitrosative stress pathways and their sequels and concomitants play a role in the pathophysiology of unipolar depression. Neurosci Biobehav Rev. 2012; 36(2): 764-785.

28. Davis SR, Shah SM, McKenzie DP, Kulkarni J, Davison SL, Bell RJ. Dehydroepiandrosterone sulfate levels are associated with more favorable cognitive function in women. $J$ Clin Endocrinol Metab. 2008; 93(3): 801-808.

29. Kushnarova NM, Korpachev VV, KorpachevaZinych AV, Hurina NM, Prybyla AV. The correlation of cortisol/DHEA and parameters of lipid profile of blood serum of patients with diabetes II type, with a different index of visceral obesity. ScienceRise. Med Sci. 2016; 1(3): 19-25. (In Ukrainian).

30. Rhee SJ, Kim EY, Kim SH, Lee HJ, Kim B, Ha K, Yoon DH, Ahn YM. Subjective depre- ssive symptoms and metabolic syndrome among the general population. Prog Neuropsychopharmacol Biol Psychiatry. 2014; 54: 223-230.

31. Baeva EV, Sokolenko VL. T-cells surface markers expression by lymphocytes of subjects exposed to low-dose radiation. Immunologiya. 1998; 3: 56-59. (In Russian).

32. Sokolenko VL. Cholesterol rate and immune system indices in people with symptoms of vegetative-vascular dystonia, who lived in the territories contaminated with radionuclides. World Med Biol. 2016; 2: 86-90. (In Ukrainian).

33. Stone WL, Dratz EA. Selenium and nonselenium glutathione peroxidase activities in selected ocular and non-ocular rat tissues. Exp Eye Res. 1982; 35(5): 405-412.

34. Emerit I, Oganesian N, Sarkisian T, Arutyunyan R, Pogosian A, Asrian K, Levy A, Cernjavski L. Clastogenic factors in the plasma of Chernobyl accident recovery workers: anticlastogenic effect of Ginkgo biloba extract. Radiat Res. 1995; 144(2): 198-205.

35. Bondia-Pons I, Ryan L, Martinez JA. Oxidative stress and inflammation interactions in human obesity. J Physiol Biochem. 2012; 68(4): 701-711.

36. Tall AR, Yvan-Charvet L. Cholesterol, inflammation and innate immunity. Nat Rev Immunol. 2015; 15(2): 104-116.

37. Melnyk TO, Sokolenko VL, Sokolenko SV. Normobaric hypoxia effects on some parameters of cellular immunity of persons with different blood groups. Fiziol Zh. 2005; 51(5): 61-64. (In Ukrainian). 